\title{
Seagrass colonization: patch formation and patch growth in Cymodocea nodosa
}

\author{
Carlos M. Duarte ${ }^{1}$, Kaj Sand-Jensen ${ }^{2}$ \\ ${ }^{1}$ Centro de Estudios Avanzados, Camino de Santa Barbara, E-17300 Blanes, Gerona, Spain \\ ${ }^{2}$ Freshwater Biological Laboratory, University of Copenhagen, Helsingørsgade 51, DK-3400 Hillerød, Denmark
}

\begin{abstract}
This study demonstrates that patch development in a Mediterranean community of Cymodocea nodosa (Ucria) Ascherson, growing over highly mobile sandy sediments, proceeds by colonization by seedlings $\left(0.047 \mathrm{~m}^{-2} \mathrm{yr}^{-1}\right)$, and subsequent patch development by the surviving seedlings $(<10 \%$ ). Increased patch cover is obtained by fast growing rhizomes (average elongation $=1.6 \mathrm{~m}$ $\left.\mathrm{yI}^{-1}\right)$, and coalescence of neighbour patches. Horizontal patch growth varied substantially among patches due to enhanced patch elongation with increasing patch size, whereas growth variance within patches was attributable to interannual differences consistent among different patches. Comparisons of the measured patch spread rates with those for other seagrasses species show substantial variability (> 2 orders of magnitude) in horizontal growth rates that implies broad differences in the potential for recovery among seagrass species.
\end{abstract}

\section{INTRODUCTION}

Extensive seagrass meadows are an important feature of coastal marine regions because they are highly productive (Stevenson 1988, Duarte 1989) and form diverse habitats for dense populations of macroinvertebrates and fish (Kenworthy et al. 1988). Moreover, they enhance particle sedimentation and protect the sediments and the coastline from erosion (Ginsberg \& Lowenstam 1958, Harlin et al. 1982). Thus, seagrass meadows are essential components of the biological and physico-chemical structure and processes of coastal areas.

Seagrass communities are characterized by dramatic fluctuations in the area they cover (e.g. Wilson 1949, Kikuchi 1974, Den Hartog \& Polderman 1975, Orth \& Moore 1983, Cambridge \& McComb 1984) due to passage of storms and hurricanes (Thomas et al. 1961, Birch \& Birch 1984, Williams 1988), the impact of human activities (e.g. Thayer et al. 1975, Kemp et al. 1983. Cambridge \& McComb 1984), and occasional disease-induced mass mortality (Short et al. 1988), followed by partial or full recovery. These fluctuations induce significant changes of the associated biotic communities (e.g. Kikuchi 1974, Rasmussen 1977), and sediments (Wilson 1949, Ginsberg \& Lowenstam 1958, Christiansen et al. 1981). Although there is a wealth of information on growth and production of established seagrass communities, there is a striking paucity of information on seagrass colonization, which precludes forecasting of the recovery of seagrass ecosystems.

Here we contribute towards filling this gap in our knowledge of seagrass ecosystems by providing a first account of the colonization process for a Mediterranean seagrass (Cymodocea nodosa (Ucria) Aschers.) community growing over highly mobile sandy sediments in shallow waters. We first asssess the success in the formation of new patches from propagules, and then evaluate the growth of established patches and quantify the magnitude and sources of variance in patch growth. Finally, we review the rates of horizontal spread of seagrass species available in the literature.

\section{STUDY AREA}

The seagrass population studied is located in the Alfaques Bay (NE Spain; $50 \mathrm{~km}^{2}$ ), a shallow $(<6 \mathrm{~m}$ ), tideless Mediterranean estuarine Bay associated with the Ebro Delta complex (Fig. 1). Erosion of an abandoned deltaic lobe of the Ebro River formed a narrow (ca $200 \mathrm{~m}$ ), $5 \mathrm{~km}$ long sandbar that separates the Bay from the adjacent Mediterranean Sea (Fig. 1; Maldonado 1972). The present surface sediments off the sandbar are uniform sands from marine inputs (Maldonado 1972), that form a wide and shallow $(<2 \mathrm{~m}$ deep) platform. The platform supports growth of Cymodocea nodosa patches and presents some relief 


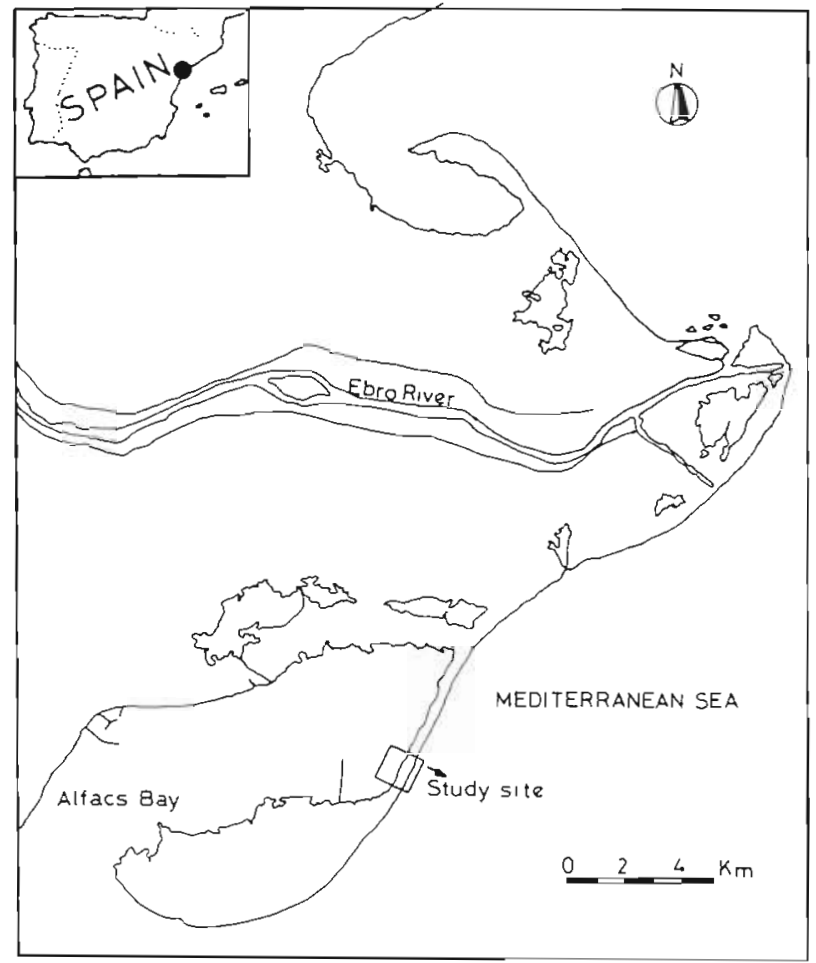

Fig. 1. The studied zone

due to the presence of highly mobile sand-waves (ca $30 \mathrm{~cm}$ high, 50 to $150 \mathrm{~m}$ apart; Maldonado 1972) that are responsible for seagrass burial.

Cymodocea nodosa, like many other seagrass species, is able to withstand burial by vertical growth $(>20 \mathrm{~cm}$ ) of the short shoots and subsequent reversal of the short shoots into rhizomes (Caye \& Meinesz 1985). However, rhizome exposure as the sand waves move out of the seagrass patches, and subsequent colonization of the exposed rhizomes by encrusting organisms (Duarte \& Sand-Jensen unpubl.), result in plant (and patch) mortality. The maximum age of $C$. nodosa plants between consecutive sandbars is ca 7 to $10 \mathrm{yr}$. This maximum age is probably set by the timescales of major sand movements (e.g. Patriquin 1975).

\section{METHODS}

Cymodocea nodosa age. The age of C. nodosa short shoots, and that of the rhizomes bearing them, can be calculated by multiplying the number of leaves produced during the life time of the shoot and the plastochrone interval (PI - the average time interval between appearance of successive leaves; Patriquin 1973). The total number of leaves developed by a particular shoot can easily be back-calculated by adding the number of standing leaves to the number of leaf scars present on the short shoot (Caye \& Meinesz 1985, Perez 1989). The age (as PI) of particular shoots could be precisely determined for shoots younger than $20 \mathrm{PI}$, and the precision in the determination of the age of older shoots was \pm 1 PI.

Although our most accurate time unit is PI, we also provide age estimates of time in days and years by using a mean plastochrone interval of $28 \mathrm{~d}$ (i.e. 13 new leaves $\mathrm{yI}^{-1}$ ), derived from a nearby Cymodocea nodosa bed in the same bay by Perez (1989). The validity of this average PI value was confirmed by its agreement with our estimate of PI obtained on the basis of the number of leaf scars equivalent to a full annual cycle as determined by (1) the seasonal sequence of rhizome internodal lengths in fast growing stolons, and (2) the seasonal sequence of leaf internodal length in seedlings. We shall use the term 'shoot' to refer to short shoots and 'rhizome' to refer to the plagiotrope, or long shoot.

Patch size distribution. Patch size distribution is the outcome of a dynamic balance between colonization and subsequent patch growth and loss (through rhizome exposure for the Cymodocea nodosa population studied). This balance could be represented mathematically by an equation relating the characteristic linear dimension ( $d$, in $m$ ) of patches (i.e. the diameter of a circle with area equivalent to that of the patch) to the proportion of smaller patches $\left(\mathrm{N}_{\mathrm{d}}\right)$. For convenience, a Von Bertalanfy equation was fitted to describe the cumulative frequency distribution of patch diameter

$$
N_{d}=100\left(1-b e^{-g d}\right)^{3}
$$

where the parameter $g=$ the fractional change in patch number with increasing patch size (i.e. the fraction of patches growing from one size class to the next); and $\mathrm{b}=\mathrm{a}$ constant reflecting the minimum size for which the curve applies.

To establish the size distribution of seagrass patches we placed 4 quadrats, covering an area equivalent to 1 ha, randomly on an aerial photograph (1:9600) of the area sampled and measured the area of the plant patches within each quadrat under a dissecting microscope fitted with a micrometer.

Patch formation, patch form, and patch growth. Patch formation was studied by examining seedling abundance and age structure. This was done by randomly locating 13 replicate $100 \mathrm{~m}^{2}$ quadrats within the study area (depth 0.20 to $0.60 \mathrm{~m}$ ). The quadrats were then screened to collect all seedlings, as well as isolated plants, and the age of all seedlings was determined from the number of standing leaf and leaf scars in the short shoot (see above). Patch form and growth (i.e. horizontal spread) was determined for 26 Cymodocea nodosa patches (sampled between July 8 and July 25,1989 ) representing a wide range in patch size (length of the main axis $<1 \mathrm{~m}$ to $30 \mathrm{~m}$ ). Patch form 
was represented by the orientation and length of the main (i.e. longest) axis, identified from measurements of patch size along every $45^{\circ}$ bearing, and the length of the longest axis perpendicular to the main axis (hereafter referred to as secondary axis). Patch growth was represented by the rate of lateral patch spread, calcu-

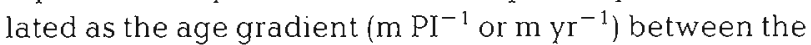
origin of the patch (i.e. the location of the oldest shoot within the patch) and the shoots located at the patch front along the transects studied.

To locate the origin of the patch and calculate the age gradient across the patch, we placed a transect along the main axis of the patch and, in the larger $(>5 \mathrm{~m}$ ) patches, a transect perpendicular to the main axis through its geometric centre (i.e. the intersection of main and secondary axes). We then located 3 to 15 (depending on patch size) uniformly spaced stations along each transect and aged all short shoots within a $0.04 \mathrm{~m}^{2}$ quadrat positioned at each station to identify the oldest shoot present (number of shoots examined in each station were 5 to 160 depending on shoot density). For the smaller patches (main axis $<1 \mathrm{~m}$ ), we determined the age of all shoots within the patch. The greatest age obtained represents, therefore, the time elapsed since this station was colonized, and the oldest station was assumed to be at, or close to, the position where the patch was initiated. The oldest shoot found provides an estimation of the minimum time elapsed since colonization, for the first shoots to colonize may have died prior to sampling. This, however, is unlikely to be an important source of error, since most patches were estimated to be younger than $6 \mathrm{yr}$, while the longevity of Cymodocea nodosa is greater than $7 \mathrm{yr}$ (Duarte \& Sand-Jensen 1990).

The measurements obtained allowed (1) the quantification of growth symmetry, measured as the ratio between patch length to either direction from the patch origin, and (2) the reconstruction of the time course of patch development. The time course of patch development was reconstructed by using the maximum shoot age (i.e. time elapsed since establishment) found in all stations sampled within a patch to draw isolines of equal maximum age (i.e. established at the same time). This procedure allowed the back-calculation of patch size and form in different years.

Patch growth in Cymodocea nodosa is achieved by centrifugal growth of linear, fast growing stolons (sensu Wittmann 1984) at the patch front. The elongation rate of these fast growing rhizomes sets the potential for patch growth into new substratum. The open space in between these fast growing stolons is subsequently filled out by branching. To assess whether patches are growing at their maximal rate we compared wholepatch growth rates derived from the transect data with the potential elongation rates, estimated as the elonga- tion rate of 18 randomly sampled fast-growing rhizomes.

\section{RESULTS}

\section{Patch formation}

The average number of new $(<1 \mathrm{yr})$ seedlings encountered was $0.047 \pm 0.016$ (SE) $\mathrm{m}^{-2}$. This small colonization rate is expected because among the $>$ 10000 shoots examined here only 4 bore fruits. Perez (1989) did not find any sexual reproduction in a 3 yr study of a nearby Cymodocea nodosa bed. Seedling distribution was highly aggregated (skewness for seedling density was 1.04), and tended to be greater in areas where previous patches had died, as reflected by exposed rhizome fragments.

The age distribution of all seedlings (Fig. 2) suggests considerable seedling mortality in the first year following germination $(>70 \%$ ), and little mortality thereafter. Rhizome development, necessary for patch formation from established seedlings, was observed in < $50 \%$ of the seedlings surviving for $2 \mathrm{yr}$ and no evidence of rhizome growth was observed in older seedlings. Consequently, seedlings may remain as isolated plants for as long as 78 PI (ca 6 yr). The suggested mortality of ca $80 \%$ of the new seedlings and the $50 \%$ patch formation rate of the surviving seedlings suggest a density of only 1 patch-forming seedling in every $217 \mathrm{~m}^{2}$.

\section{Patch size distribution}

The size distribution of Cymodocea nodosa patches was strongly skewed (Fig. 3). The decrease in the number of patches smaller than the mode $\left(64 \mathrm{~m}^{2}\right.$; Fig. 3) is probably an artifact because of the increasing difficulty in detecting patches on the aerial photograph

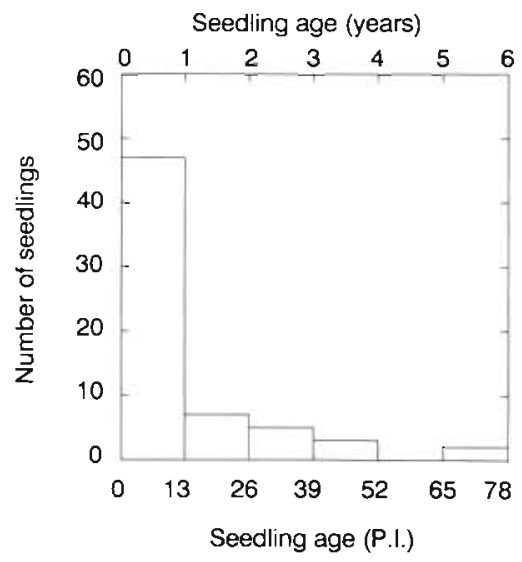

Fig. 2. Cymodocea nodosa. Age distribution of all seedlings encountered 


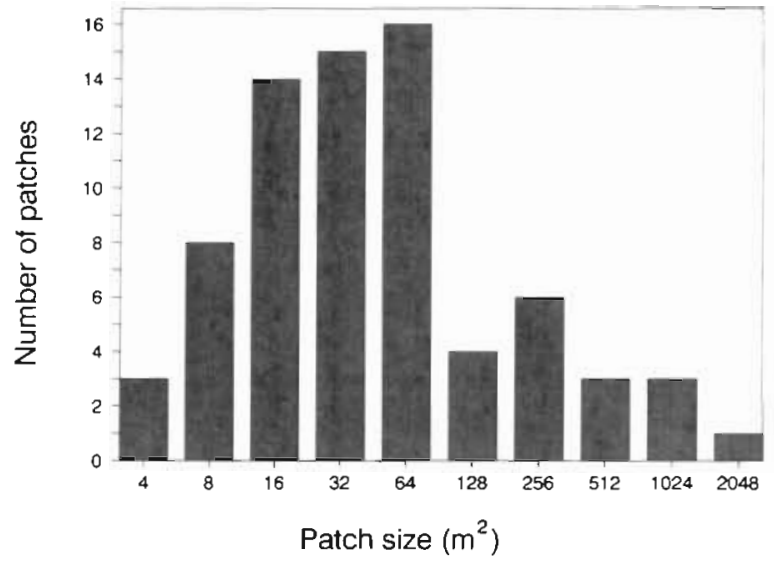

Fig. 3. Cymodocea nodosa. Logarithmic $\left(\log _{2}\right)$ size distribution of patches. Numbers on abscissa represent the mode of each size class

as their size decreases, although it may also derive from interannual variability in patch formation. Therefore, we used only the size classes $>32 \mathrm{~m}^{2}$ to calculate the exponential rate constant of patch size change ( $g$, Eq. 1). The value obtained $(0.32 \pm 0.009 \mathrm{SE})$ reflects a small probability of transfer of patches from one size class to the next. The rate of change in patch size, however, results both from patch growth and coalescence with neighbour patches. Since patch-forming seedlings are separated, on average, by ca $16 \mathrm{~m}$, patch coalescence should be most common at patch sizes of ca $220 \mathrm{~m}^{2}$. Patch coalescence can, therefore, account for the secondary peak in patch abundance observed for the $256 \mathrm{~m}^{2}$ size class (Fig. 3).

\section{Patch growth}

The size (average radius, $m$ ) of plant patches was linearly related to the time (yr) since establishment (i.e patch age; Fig.4). The equation describing this relationship,

$$
\begin{gathered}
\text { Patch length }=1.32 \text { Age }-1.7 \\
\left(\mathrm{R}^{2}=0.53, \mathrm{~N}=19, \mathrm{SE}_{\text {slope }}=0.60\right)
\end{gathered}
$$

implies an average patch growth of about $0.10 \mathrm{~m} \mathrm{PI}^{-1}$, or $1.32 \pm 0.60(\mathrm{SE}) \mathrm{m} \mathrm{yr}^{-1}$, similar $(\mathrm{p}>0.05)$ to the average elongation rate found for fast-growing rhizomes $\left(1.58 \pm 0.79 \mathrm{~m} \mathrm{yr}^{-1}\right)$. There was, however, considerable scatter in the relationship between patch size and age (Fig. 4), demonstrating high variance in growth rate of individual patches (Fig. 5).

The variance in patch growth results partially from asymmetric patch growth, because the geometric centre was displaced relative to the patch origin (Fig. 6), resulting in elongated patches. In addition, the deviation of the patches from a circular form las measured by main-axis to secondary axis length ratios

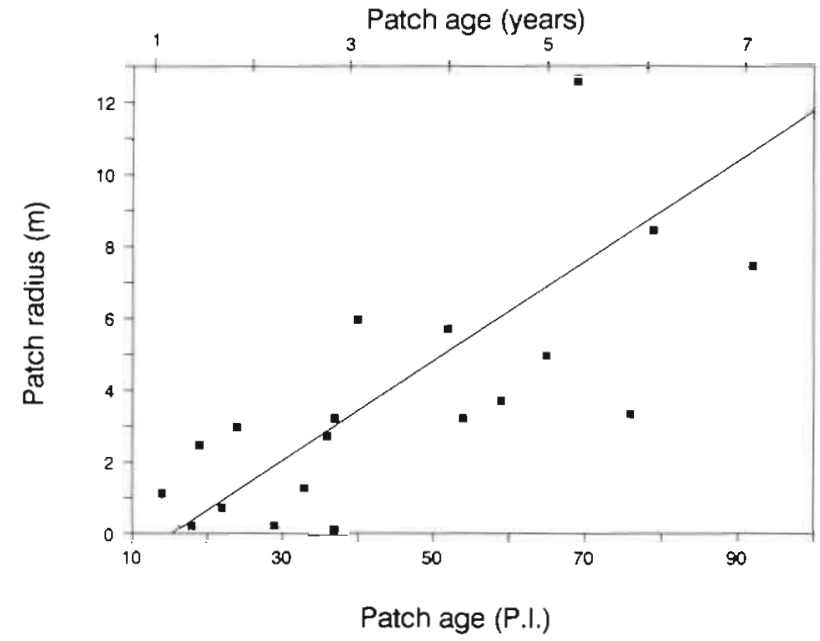

Fig. 4. Cymodocea nodosa. Relationship between patch age and the average radius of patches. Line represents the regression equation (Eq. 2)

greater than 1) increased with increasing patch size (r $=0.76 ; \mathrm{p}<0.01$ ). Further, the main axis was not randomly oriented (Rayleigh test for randomness of bearing, $p<0.001$; Batschelet 1981), but were oriented mainly between NW-SE and N-S (Fig. 6). Variance in patch growth was partially a function of size, because lateral growth increased with increasing patch size (Fig. 7). This relationship was best described by the regression equation

Patch growth $\left(\mathrm{cm} \mathrm{PI}^{-1}\right)=1.2+2.1$ Radial length $(\mathrm{m})$

$$
\left(\mathrm{R}^{2}=0.85, \mathrm{~F}=231, \mathrm{p}<0.0001, \mathrm{~N}=37\right)
$$

Reconstruction of the time series of patch size and form changes (Fig. 8) illustrates the development of asymmetry in patch growth and reveals temporal variability in patch elongation rates in specific directions (Fig. 8). To examine whether variability of patch growth in specific directions was age-dependent or due to interannual differences we assembled the time course of relative patch growth (the proportion of the total radial growth produced in consecutive years) for patches of similar age. This showed the occurrence of year-to-year variability in patch growth involving a 3 fold decrease in patch elongation rates after 1987. when elongation rates were highest (Fig. 9). This pattern is consistent for patches established in different years (Fig. 9), demonstrating that the variability in elongation rates observed is independent of patch age and probably reflects different conditions for patch expansion in different years.

\section{DISCUSSION}

Patch formation in the Cymodocea nodosa community studied appears driven by sexual reproduction. We 


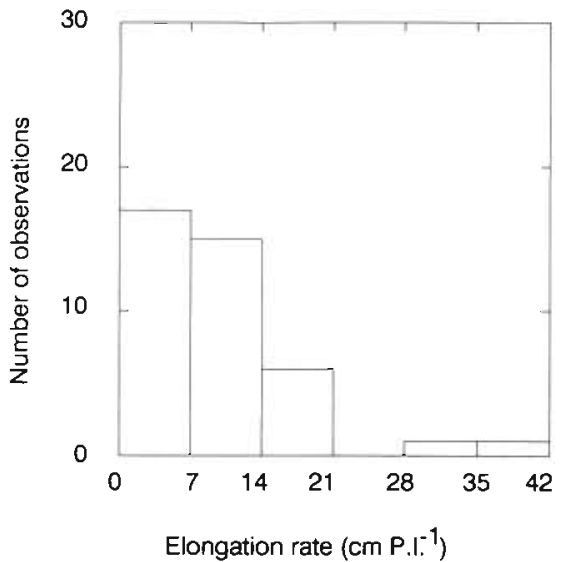

Fig. 5. Cymodocea nodosa. Frequency distribution of measured patch elongation rates
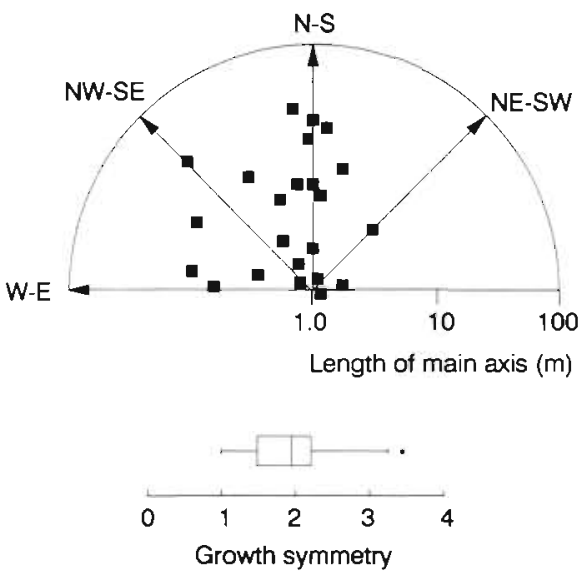

Fig. 6. Cymodocea nodosa. Orientation of patches in relationship to patch size (i.e. length of main axis; above), and frequency distribution of symmetry (below), measured as the ratio between distance from patch origin to patch margin for each side of the transect

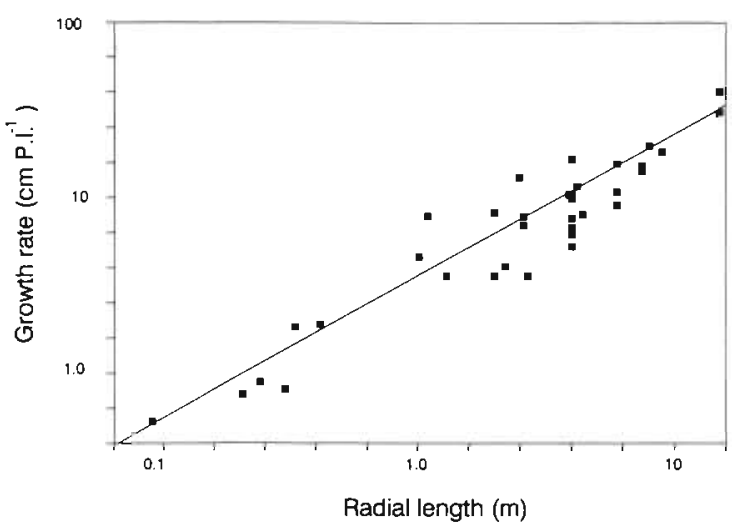

Fig. 7. Cymodocea nodosa. Relationship between patch elongation rates and patch size (as distance from patch origin to patch margin)
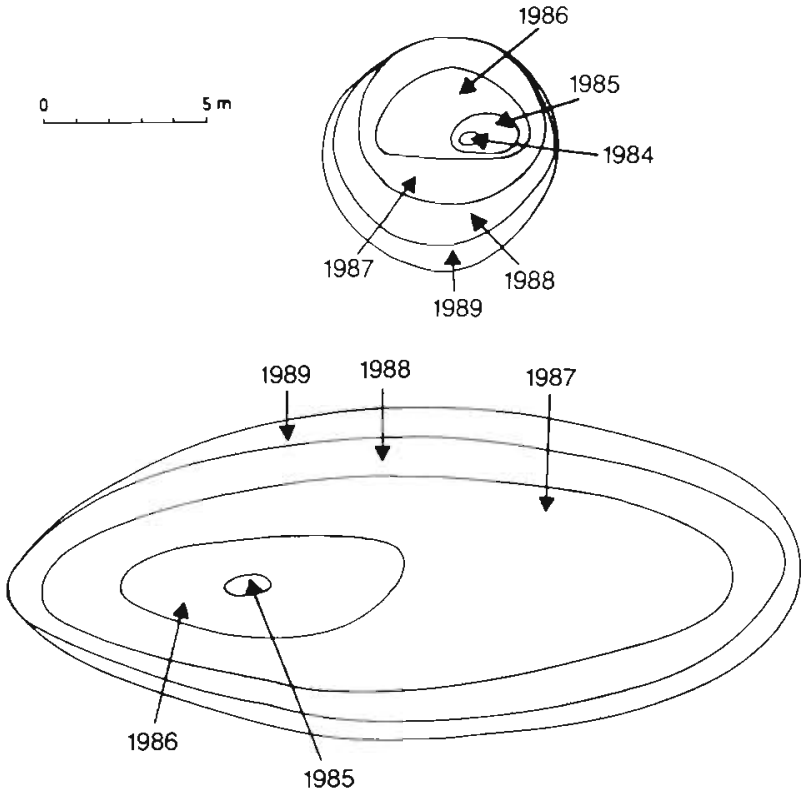

Fig. 8. Cymodocea nodosa. Reconstruction of time course of patch form and size for 2 selected patches

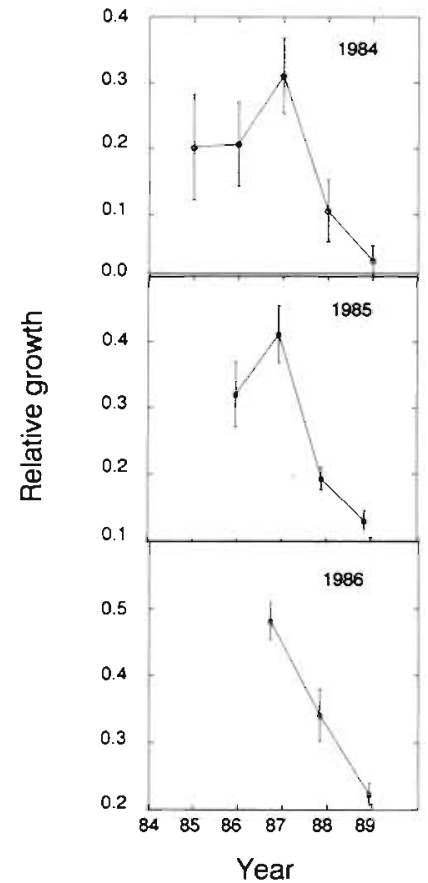

Fig. 9. Cymodocea nodosa. Relative growth rate of patches formed in 1984, 1985, and 1986. Relative growth rate is shown as the fraction of the total radial growth produced in consecutive years (due to the averaging process, the fractions do not add up to 1). Mean values \pm SE shown

found many seedlings, but failed to detect any isolated plant that developed from rhizome segments. Thus, lack of significant sexual reproduction (only 4 fruits found in $>10000$ shoots examined) does not imply that vegetative propagation must be the dominant reproductive mode. Patch formation from sexual propagules 
is, however, highly inefficient, due to seed and seedling mortality during propagule development, and because seedling establishment does not ensure seedling development into patches. Thus, the patch formation rate obtained for the community studied (45 patches $\mathrm{ha}^{-1} \mathrm{yr}^{-1}$ j is much smaller than the rate of seedling appearance (470 seedlings $\mathrm{ha}^{-1} \mathrm{yr}^{-1}$ ). The sources of seedling mortality and the factors determining whether seedlings develop into patches are, as yet, unknown. Nevertheless, the resulting patch formation rate is still greater than that reported for the Mediterranean seagrass Posidonia oceanica (L.) Delile (3 $\mathrm{yr}^{- \text {: }}$ $\mathrm{ha}^{-1}$; Meinesz \& Lefevre 1984). Seedling development in these Mediterranean species is rare (Caye \& Meinesz 1985, Perez 1989) compared to other species (e.g. Zostera marina growing in Atlantic waters) where seedling appearance may occasionally be $>1000 \mathrm{~m}^{-2}$ $\mathrm{yr}^{-1}$ (Robertson \& Mann 1984), which should, consequently, ensure greater patch formation rates.

Patch formation, however, is still insufficient to ensure successful colonization, because the positively skewed patch size distribution obtained (Fig. 3) indicates substantial patch loss (e.g. through burial and subsequent rhizome exposure) during growth. The size distribution for Posidonia oceanica patches recovering from a submarine explosion (Meinesz \& Lefevre 1984) was also positively skewed. Visual examination of aerial photographs of other patchy seagrass populations (e.g. Figs, 3 and 5 in Kelly 1980, Fig. 23 in Thayer et al. 1984) further suggests that positively skewed patch size distributions are the rule in patchy seagrass stands. The patch diameter distribution of the $P$. oceanica population (from Fig. 3 in Meinesz \& Lefevre 1984) yielded and exponential rate constant of change in patch abundance $(g)$ of $0.77 \pm 0.007\left(\mathrm{SE}_{;} \mathrm{R}^{2}=0.99\right)$, indicating a smaller patch loss with increasing size than that in the present study ( $g=0.32$ ). This dissimilarity in patch size distribution may reflect differences in the extent of disturbance experienced by colonizing plants. The use of $g$ parameters may prove useful in comparing and summarizing the dynamic aspects reflected in patch size distributions. Colonization of environments subject to low-frequency disturbance should result in greater $g$ values than those expected in frequently disturbed areas, where fewer patches should 'escape' disturbance to reach large sizes. Thus, the amplitude and frequency (relative to patch growth) of disturbance appear to be major determinants of the patch size distribution, and the extent of spatial heterogeneity of colonizing seagrass (cf. Duarte 1990).

The average patch growth equalled the average potential rate set by the growth of fast-running rhizomes over bare substrate. Patch growth is, therefore, tightly controlled by seagrass capacity for rhizome growth (Tomlinson 1974) Patch growth of Cymodocea nodosa was subject to considerable variability among and within patches. These differences result from interannual, environmentally determined, differences in patch growth consistent among patches (Fig. 9), and from the fact that patch growth is accelerated as patch size increases (Fig. 7). This growth acceleration explains the asymmetric shape of the patches (Fig. 6), because small differences in patch growth along the different directions are enhanced as patches elongate. This finding supports previous suggestions of positive feed-backs in seagrass growth (McRoy \& Lloyd 1981, Fig. 5 in Fonseca et al. 1983).

Once established, seagrasses modify their environment by forming a compact layer that deflects currents above them (e.g. Fonseca et al. 1982, Fonseca et al. 1983, Thayer et al. 1984) and their rhizomes and roots stabilize the underlying sediments against erosion. Furthermore, the reduced current velocities within the patch contribute to increase sedimentation and reduce sediment resuspension within the patch (Fonseca et al. 1983, Harlin et al. 1982. Thayer et al. 1984). Thus, increased patch size and density may lead to improved growth conditions, in a positive feed-back process (McRoy \& Lloyd 1981, Fonseca et al. 1983), such that seagrass patches form a 'mutually sheltering structure' (Thayer et al 1984) as they grow.

The potential for seagrass colonization is a function of both the rhizome elongation, which determines patch growth, and reproductive effort, which sets the potential for formation of new patches. Information on elongation rates of seagrass rhizomes is sparse, but the available data demonstrate considerable variability among and within species (Fig. 10). Some species are able to elongate several meters per year (e.g. Cymodocea spp. and Syringodium isoetifolium), whereas some others (e.g. Posidonia oceanica, Thalassoden dron pachyrhizum, Zostera marina) grow at rates of only a few centimetres per year (Fig. 10). Nevertheless, some species with slow elongation rates (e.g. Z . marina) may achieve a high potential for colonization by having a high reproductive effort. $P$. oceanica, which exhibits both very slow elongation rates and rare sexual reproduction, may develop extensive meadows only because of its extreme genet longevity ( $>1000 \mathrm{yr}$; Boudouresque et al. 1980, Calmet et al. 1988). The absence of direct reports on the horizontal growth rates for $Z$. marina, which has been studied for almost a century, is symptomatic for the general neglect of rhizome growth and plant colonization aspects (Bell \& Tomlinson 1980). The paucity of studies on seagrass colonization contrasts with the worldwide alarm caused by recent seagrass declines (e.g. Wilson 1949, Kikuchi 1974, Den Hartog \& Polderman 1975, Orth \& Moor 1983, Cambridge \& McCom 1984). Therefore, the results obtained in this study of seagrass patch forma- 


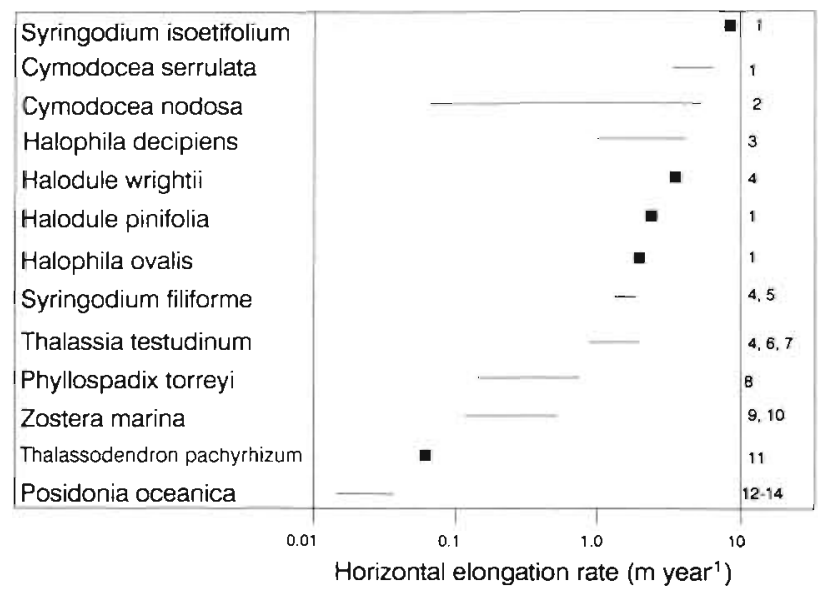

Fig. 10. Horizontal elongation rates of seagrass species. Single values are represented by full squares and lines cover the range when multiple values were reported. References (on the right) correspond to 1 , Brouns $(1987) ; 2$, this study; 3 , Josselyn et al. (1986); 4, Eleuterius (1987); 5. Patriquin (1975); 6, Patriquin (1973); 7, Durako \& Moffler (1985); 8, Stewart (1989); 9 , Jacobs (1984); 10, Sand-Jensen (1975); 11, Kirkman \& Cook (1987); 12, Calmet et al. (1988); 13, Meinesz \& Lefevre (1984); 14, Wittmann (1984)

tion and growth may provide a useful framework for future efforts by (1) providing a methodological approach; (2) identifying the steps involved in the process of seagrass recovery (seedling establishment, patch initiation, patch growth); (3) providing specific testable hypotheses (e.g. the existence of positive feedbacks on patch growth); and (4) identifying areas where further research is most needed (e.g. rhizome elongation rates, time scales of seagrass recovery, sources of seedling and patch mortality).

Acknowledgements. This research was funded by a grant of the CSIC to C.M.D. and an SNF grant to K.S.J. We thank G. Duarte, J. Duarte, S. Agusti, B. Vidondo, T Jespersen and T. Sand-Jespersen for assistance in the field, J. Romero and $M$. Perez for useful suggestions on methods, and E. Ballesteros, J. Borum, and 2 anonymous reviewers for useful comments on the manuscript.

\section{LITERATURE CITED}

Batschelet, E. (1981). Circular statistics in biology. Academic, New York

Bell, A. D., Tomlinson, P. B. (1980). Adaptative architecture of rhizomatous plants. Bot. J. Linn. Soc. 80: 125-160

Birch, W. R., Birch, M. (1984). Succession and pattern of tropical intertidal seagrasses in Cockle Bay, Queensland, Australia: a decade of observations. Aquat. Bot. 19: 343-367

Boudouresque, C. F., Giraud, G., Thommeret, J., Thommeret, Y. (1980). First attempt at dating by ${ }^{14} \mathrm{C}$ the undersea beds of dead Posidonia oceanica in the Bay of Port-Man (PortCros, Var, France). Trav. scient. Parc natn. Port-Cros 6: 239-242

Brouns, J. J.W. M. (1987). Growth patterns of some IndoWest-Pacific seagrasses. Aquat. Bot. 28: 39-61
Cambridge, M. L., McComb, A. J. (1984). The loss of seagrasses in Cockburn Sound, Western Australia. I. The time course and magnitude of seagrass decline in relation to industrial development. Aquat. Bot. 20: 229-243

Calmet, D., Boudouresque, C. F., Meinesz, A. (1988). Memorization of nuclear atmospheric tests by rhizomes and scales of the Mediterranean seagrass Posidonia oceanica (Linnaeus) Delile. Aquat. Bot. 30: 279-294

Caye, G., Meinesz, A. (1985). Observations on the vegetative development, flowering and seeding of Cymodocea nodosa (Ucria) Ascherson on the Mediterranean coasts of France. Mar. Ecol. Progr. Ser. 22: 277-289

Christiansen, C., Christoffersen, H., Dalsgaard, J., Nornberg, R. (1981). Coastal and nearshore changes correlated with die-back in eelgrass (Zostera marina L.). Sedimentary Geol. 28: 163-173

Den Hartog, C., Polderman, P. J. G. (1975). Changes in the seagrass populations of the Dutch Waddenzee. Aquat. Bot. 1: 141-147

Duarte, C. M. (1989). Temporal biomass variability and production/Biomass relationships of seagrass communities. Mar. Ecol. Prog. Ser. 51: 269-276

Duarte, C. M. (1990). Variance and the description of nature. In: Cole, J. J. (ed.) Comparative ecology of ecosystems: patterns, mechanisms, and theories. Springer-Verlag, Heidelberg (in press)

Duarte, C. M., Sand-Jensen, K. (1990). Seagrass colonization: Biomass development and shoot demography in Cymodocea nodosa patches. Mar. Ecol. Prog. Ser (in press)

Durako, M. J., Moffler, M. D. (1985). Spatial influences on temporal variations in leaf growth and chemical composition of Thalassia testudinum Banks ex Konig in Tampa (in press) Bay. Gulf Res. Rep. 8: 43-49

Eleuterius, L. N. (1987). Seagrass ecology along the coasts of Alabama, Louisana, and Mississippi, In: Durako, M. J., Phillips, R. C., Lewis, R. R., III (eds.) Proc. Symp. Subtropical-Tropical seagrasses Southeastern United States. Fla mar. Res. Publs 42: 11-20

Fonseca, M. S., Fisher, J. J., Zieman, J. C., Thayer, G. W (1982). Influence of the seagrass, Zostera marina L., on current flow. Estuar. coast. Shelf Sci. 15: 351-364

Fonseca, M. S., Zieman, J. C., Thayer, G. W., Fisher, J. S. (1983). The role of current velocity in structuring seagrass (Zostera marina L.) meadows. Estuar coast. Shelf Sci. 17: $367-380$

Ginsberg, R. N., Lowenstam, H. A. (1958). The influence of marine bottom communities on the deposition environment of sediments. J. Geol. 66: 310-318

Harlin, M. M., Thorne-Miller, B., Boothroyd, J. C. (1982). Seagrass-sediment dynamics of a flood-tidal delta in Rhode Island (U.S.A.). Aquat. Bot. 14: 127-138

Jacobs, R. P. W. M. (1984). Biomass potential of eelgrass (Zostera marina L.). CRC critical Rev. Pl. Sciences 2: 49-80

Josselyn, M., Fonseca, M., Niesen, T., Larson, R. (1986). Biomass, production and decomposition of a deep water seagrass, Halophila decipiens Ostenf. Aquat. Bot. 25: 47-61

Kelly, M. G. (1980). Remote sensing of seagrass beds. In: Phillips, R. C., McRoy, C. P. (eds.) Handbook of seagrass biology: an ecosystem perspective. Garland, New York, p. $69-85$

Kemp, W. M., Twilley, R. R., Stevenson, J. C., Boynton, W. R., Means, J.C. (1983). The decline of submerged vascular plants in upper Chesapeake Bay: summary of results concerning possible causes. Mar. Techn. Soc. J. 17: 78-89

Kenworthy, W. J., Thayer, G. W., Fonseca, M. S. (1988). The utilization of seagrass meadows by fishery organisms. In: Hook, D. D., McKee, W. H. Jr., Smith, H. K., Gregory, J., 
Burrell, V. G. Jr., DeVoe, M. R., Sojka, R. E., Gilbert, S., Blanks, R., Stolzy, L. H., Brooks, C, Matthews, T D., Shear, T. H. (eds.) The ecology and management of wetlands, Vol 1. Timber Press, Oregon, p. 548-560

Kikuchi, T. (1974). Japanese contributions on consumer ecology in eelgrass (Zostera marina L.) beds, with special reference to trophic relations and resource inshore fisheries. Aquaculture 4: 145-160

Kirkman, H., Cook, I. H. (1987). Distribution and leaf growth of Thalassodendron pachyrhizum Den Hartog in Southern Western Australia. Aquat. Bot. 27: 257-266

Maldonado, A. (1972). El Delta del Ebro. Estudio sedimentológico y estatigráfico. Boletín de Estatigrafía vol. 1. Universidad de Barcelona

McRoy, C. P., Lloyd, D. B. (1981) Comparative function and stability of macrophyte-based ecosystems. In: Longhurst, A. R. (ed.) Analysis of marine ecosystems. Academic Press, London, p. 473-489

Meinesz, A., Lefevre, J.-R. (1984). Regeneration d'un herbière de Posidonia oceanica quarante annes après sa destruction par une bombe dans la rade de Villefranche (AlpesMaritimes, France). In: Bouderesque, C. F., Jeudy de Grissac, A., Olivier, J. (eds.) International workshop on Posidonia oceanica beds. G.I.S. Posidonie, Marseille, p. $39-44$

Orth, R. J., Moore, K. A. (1983). Chesapeake Bay: an unprecedent decline in submerged aquatic vegetation. Science 222: $51-53$

Patriquin, D. (1973). Estimation of growth rate, production and age of the marine angiosperm Thalassia testudinum Konig. Caribb. J. Sci. 13: 111-123

Patriquin, D. G. (1975). 'Migration' of blowouts in seagrass beds at Barbados and Carriacou, West Indies, and its ecological and geological implications. Aquat. Bot. 1. $163-189$

Perez, M. (1989). Fanerogamas marinas en sistemas estuaricos: producción, factores limitantes y algunos aspectos del ciclo de nutrientes. Ph. D. thesis, Universidad de Barcelona

Rasmussen, E. (1977). The wasting disease of eelgrass (Zost-

This article was presented by Dr G. W. Thayer, Beaufort, North Carolina, USA era marina) and its effect on environmental factors and fauna. In: McRoy, C. P., Helfferich, C. (eds.) Seagrass ecosystems, a scientific perspective. Marcel Dekker, New York, p. 1-51

Robertson, A. I., Mann, K. H. (1984). Disturbance by ice and life-history adaptations of the seagrass Zostera marina. Mar. Biol. 80: 131-141

Sand-Jensen, K. (1975). Biomass, net production and growth dynamics in an eelgrass (Zostera marina L.) population in Vellerup Vig, Denmark. Ophelia 14: 185-201

Short, F. T., Ibelings, B. W., Den Hartog, C. (1988). Comparison of a current eelgrass disease to the wasting disease in the 1930s. Aquat. Bot. 30: 295-304

Stevenson, J. C. (1988). Comparative ecology of submerged grass beds in freshwater, estuarine, and marine environments. Limnol. Oceanogr. 33: 867-893

Stewart, J. G. (1989). Maintenance of a balanced, shifting boundary between the seagrass Phyllospadix and algal turf. Aquat. Bot. 33: 223-241

Thayer, G. W., Wolfe, D. A. Williams, R. B. (1975). The impact of man on seagrass systems. Am. Scient. 63: 288-296

Thayer, G. W., Kenworthy, W. J., Fonseca, M. S. (1984). The ecology of eelgrass meadows of the Atlantic coast: a community profile. U.S. Fish Wildl. Serv. FWS/OBS-84/02: $1-147$

Thomas, L. P., Moores, D. R., Work, R. C. (1961). Effects of hurricane Donna on the turtle-grass beds of Biscayne Bay, Florida. Bull. mar Sci. 11: 191-197

Tomlinson, P. B. (1974). Vegetative morphology and meristem dependence - the foundation of productivity in seagrasses. Aquaculture 4: 107-130

Williams. S. L. (1988). Disturbance and recovery of a deepwater Caribbean seagrass bed. Mar. Ecol. Progr. Ser. 42: $63-71$

Wittmann, K. J. (1984). Temporal and morphological variations of growth in a natural stand of Posidonia oceanica (L.) Delile. Pubbl. Staz. zool. Napoli (I. Mar. Ecol.) 5: 301-316

Wilson, D. P. (1949). The decline of Zostera marina L. at Salcombe and its effects on the shore. J. mar. biol. Ass. U.K. 28: 395-412

Manuscript first received: January 23, 1990

Revised version accepted: May 28, 1990 